\title{
Protein degradability in the rumen and intestinal digestibility of ensiled whole-crop oat cut at different stages of maturity*
}

\author{
Z.M. Kowalski ${ }^{1}$, F. Borowiec ${ }^{1}$, P.M. Pisulewski ${ }^{2}$, P. Micek ${ }^{1}$ \\ and J. Ludwin'
}

Cracow Agricultural University,

'Department of Animal Nutrition

Al. Mickiewicza 24/28, 30-059 Kraków, Poland

'Department of Human Nutrition

29 Listopada 46, 31-425 Kraków. Poland

\begin{abstract}
Ruminal protein degradability and intestinal rumen-undegraded protein digestibility (IDRUP) of whole-crop oat cut at: heading (H), milk (M) and milk-dough (M-D) stages of maturity were measured. The experiment was conducted on three Holstein bulls fitted with ruminal and duodenal cannula using the in situ and mobile nylon bag methods.

A significant effect of ensiling on rumen protein degradability parameters was shown. Ensiling increased both protein solubility (fraction $A$ ) and effective rumen degradability (ERD), decreased the content of potentially degradable fraction $B(P<0.001)$ and IDRUP $(64.7$ vs $55.3 \% ; P<0.001)$. The content of soluble fraction (A) and ERD increased, and the content of fraction (B) decreased from heading ( $\mathrm{H}$ ) to milk (M) stages. However, from $\mathrm{M}$ to $\mathrm{M}-\mathrm{D}$ stages of growth, the content of fraction $\mathrm{A}$ (75.6 vs 70.5) and ERD (80.6 vs 78.2) decreased. Total tract protein digestibility decreased ( $<<0.001)$ with increasing plant maturity. Moreover, IDRUP of $M$ and $M-D$ forages was lower than that of $H$ forages $(62.9,56.3$ and 56.6 , respectively for $\mathrm{H}, \mathrm{M}$ and $\mathrm{M}-\mathrm{D} ; \mathrm{P}<0.001)$.

It can be concluded that in terms of protein availability from the gastrointestinal tract, the milk stage of growth seens to be the optimal harvest time.
\end{abstract}

KEY WORDS: whole-crop oat silage, stage of maturity, protein, rumen degradability, intestinal digestibility

\footnotetext{
- Supported by the State Committec for Scientific Research, Grant No. 5 P06E 00215
} 


\section{INTRODUCTION}

Whole-crop cereal silages, including oat silage (WCOS), can be an alternative for maize silage in some areas of Poland. Their nutritive value strongly depends on the stage of maturity (Garnsworthy and Stokes, 1993; Khorasani et al., 1997; Borowiec et al., 1998). As the plant matures, the content of starch increases and nitrogen decreases. However, progressing lignification of cell walls as a result of maturation, may impair the availability of protein from the non-grain parts of the plant. In this context, evaluation of the optimal harvest time of whole cereal crop should take into account not only the starch content, but also the availability of other nutrients.

The aim of this study was to determine ruminal protein degradability and intestinal rumen-undegraded protein digestibility of WCOS cut at different stages of maturity.

\section{MATERIAL AND METHODS}

Whole-crop oat (var. Santor; WCO) was cut at 3 stages of maturity: heading (H), milk (M) and milk-dough of grain (M-D). After chopping and mixing ( $\left.10 \mathrm{~g} \mathrm{dT}^{-1}\right)$ with the bacterial silage additive, Microsil $\left(10 \times 10^{9} \mathrm{CFU} \mathrm{g}^{-1}\right)$, the green herbage was ensiled in $100 \mathrm{~L}$ plastic containers ( 2 silos for each stage of maturity). Five-kg samples of each green herbage were also stored at $-18^{\circ} \mathrm{C}$ for subsequent analyses. Samples of silages and green forages were dried for $48 \mathrm{~h}$ in a forced-air oven at $50^{\circ} \mathrm{C}$, and ground to pass through a $1.5 \mathrm{~mm}$ screen. The chemical composition of feeds was determined as given in Micck et al. (2001).

Three Holstein bulls ( $\pm 300 \mathrm{~kg}$ liveweight), fitted with rumen and T-type duodenal cannulas, were used in the experiment. The animals were given a standard daily ration (about $15 \% \mathrm{CP}$ in DM) of $4.8 \mathrm{~kg}$ (DM) grass hay and $2 \mathrm{~kg}$ of concentrate. Ruminal protein degradability and total tract protein digestibility (TTPD) were determined using polyester bags with a pore size $50 \pm 15 \mu \mathrm{m}$ (Ankom Technology, Fairport NY, USA). For the degradability study, each $6 \times 13 \mathrm{~cm}$ bag was filled with about $3 \mathrm{~g}$ of dried sample, but $1.2 \mathrm{~g}$ samples in $6 \times 5 \mathrm{~cm}$ bags were used in the TTPD study. The bags were incubated in the rumen for $0,2,4,8,16,24,48$, and $72 \mathrm{~h}$. Three bags per time of incubation in the animal $(\mathrm{n}=9)$ were used for each feed. The bags for the TTPD study were first incubated in the rumen for $16 \mathrm{~h}$, then in pepsin- $\mathrm{HCl}\left(2.5 \mathrm{~h} ; \mathrm{pH}=2.0 ; 39.5^{\circ} \mathrm{C}\right)$, and finally inserted into the duodenum. There were five bags per animal for each feed. The bags were collected from the faeces within $24 \mathrm{~h}$ (Kowalski et al., 1995, 1997).

The nitrogen content in residues after rumen incubation was analyzed in pooled samples for each animal. To correct for microbial contamination, DAPA was determined according to Czauderna and Kowalczyk (1999). 
The degradability data obtained for each animal were regressed against incubation time using a model $\mathrm{d}=\mathrm{a}+\mathrm{b}\left(1-\mathrm{e}^{-\mathrm{ct}}\right)$ (Ørskov and McDonald, 1979) and Proc NLIN of SAS (1985). Effective degradability (ED) was calculated with the outflow rate $k=0.06 h^{-1}$, using the equation $E D=a+(b \times c) /(c+k)$. TTPD was calculated as the difference between the amount of CP in the sample and in the faeces. TTPD was used to calculate the intestinal digestibility of rumen-undegraded protein (IDRUP), using the equation IDRUP $=100 \times(\mathrm{CP} \times(100-\mathrm{Dg} 16)-\mathrm{CP}$ $\mathrm{x}(100-\mathrm{TTPD})) /(\mathrm{CP} \times(100-\mathrm{Dg} 16))$, where $\mathrm{Dg} 16$ is $16 \mathrm{~h}$ degradability in the rumen (Kowalski et al., 1995).

All data were analyzed by two-way analysis of variance using the GLM procedure of SAS (1985).

\section{RESULTS AND DISCUSSION}

The advancing maturity of WCO increased DM and starch and decreased protein contents (Table 1), in line with the results of others (Borowiec et al., 1998; Edmisten et al., 1998). Some losses of DM and starch due to ensiling were shown.

Irrespective of the stage of maturity, there was a significant effect of ensiling on rumen protein degradability parameters, with the exception of degradability rate (fraction C; Table 2). Ensiling increased both protein solubility (fraction A) and effective rumen degradability (ERD), but decreased the content of potentially degradable fraction $\mathrm{B}(\mathrm{P}<0.001)$. Mean $\mathrm{A}, \mathrm{B}, \mathrm{C}$ and $\mathrm{ERD}$ values for green forages and silages were $61.2,24.0,0.129,76.4$ and $78.5,9.1,0.073,82.1$, respectively. Based on these results, WCOS should be classified as a forage with highly degradable protein. According to Coblentz et al. (2001) cereal-grain forages exhibit similar characteristics of high $\mathrm{N}$ disappearance and low potential ruminal escape

TABLE 1

Chemical composition of whole-crop oat before and after ensiling

\begin{tabular}{lcccrr}
\hline \multirow{2}{*}{ Item } & Dry matter \% & \multicolumn{5}{c}{$\%$ DM } \\
\cline { 4 - 6 } & & organic matter & crude protein & starch & NDF \\
\hline Before ensiling & & & & & \\
heading & 18.7 & 89.5 & 11.0 & 1.7 & 12.5 \\
milk & 23.5 & 92.7 & 9.7 & 14.7 & 9.4 \\
milk-dough & 29.5 & 93.4 & 7.4 & 16.7 & 14.9 \\
Silage & & & & & \\
heading & 16.3 & 89.9 & 11.6 & 1.3 & 9.3 \\
milk & 24.6 & 92.2 & 7.4 & 11.3 & 13.1 \\
milk-dough & 27.1 & 92.1 & 7.6 & 13.0 & 13.8 \\
\hline
\end{tabular}


TABLE 2

Ruminal protein degradability parameters $(A, B, C)$ and effective rumen degradability (ERD) of wholc crop oat before and after ensiling

\begin{tabular}{|c|c|c|c|c|}
\hline \multirow{2}{*}{ Item } & \multicolumn{3}{|c|}{ Degradability parameters } & \multirow{2}{*}{ ERD } \\
\hline & $\bar{A}$ & $\mathrm{~B}$ & $\mathrm{C}$ & \\
\hline \multicolumn{5}{|l|}{ Before ensiling } \\
\hline heading & 49.5 & 37.3 & 0.128 & 74.8 \\
\hline milk & 73.3 & 13.2 & 0.107 & 81.3 \\
\hline milk-dough & 60.9 & 21.3 & 0.153 & 73.1 \\
\hline \multicolumn{5}{|l|}{ Silage } \\
\hline heading & 77.5 & 11.2 & 0.067 & 83.2 \\
\hline milk & 77.8 & 9.6 & 0.082 & 79.9 \\
\hline milk-dough & 80.2 & 6.8 & 0.077 & 83.3 \\
\hline SEM $^{1}$ & 2.7 & 2.8 & 0.015 & 1.0 \\
\hline \multicolumn{5}{|l|}{ Effect } \\
\hline feed & $* * *$ & $* * *$ & NS & **** \\
\hline cut & $* * *$ & $* * *$ & NS & $* * *$ \\
\hline interaction & $* * *$ & $* * *$ & NS & $* * *$ \\
\hline
\end{tabular}

' SEM - standard error of the mean

*** $-\mathrm{P}<0.001$; NS - not significant

that are commonly observed in grasses harvested at similar growth stages. Ensiling also significantly decreased IDRUP (64.7 vs 55.3\%; $\mathrm{P}<0.001$; Table 3 ). Even so, TTPD was slightly but significantly higher in silages $(89.3 \%)$ than in green herbages $(88.5 \%)(\mathrm{P}<0.001)$. Lower intestinal digestibility of rumen-undegraded protein in silages may have resulted from the higher protein rumen degradability. Some of the protein that is degraded in the rumen could also have been digested postruminally.

Irrespective of the feed (green forage or silage), stage of maturity had a significant effect $(\mathrm{P}<0.001)$ on rumen protein degradability parameters, except on the rate of degradability (Table 2), as well as on TTPD and IDRUP (Table 3). Plant growth from heading $(\mathrm{H})$ to milk $(\mathrm{M})$ stages increased the content of soluble fraction $\mathrm{A}$ and ERD and decreased the content of fraction $\mathrm{B}$. Further plant growth from $M$ to milk-dough (M-D) stage significantly decreased the content of fraction A (75.6 vs 70.5) and ERD (80.6 vs 78.2). The effects of maturity were stronger in material before ensiling (significant interaction), since there were no such differences among silages. It is possible that lignification of the cell walls "captures" protein inside the cells and impairs its availability (Coblentz et al., 
2001). The effect seems to be strong enough to also inhibit postruminal protein digestion. As a result, with increasing maturity total tract protein digestibility decreased $(\mathrm{P}<0.001$; Table 3). Moreover, IDRUP of $\mathrm{M}$ and $\mathrm{M}-\mathrm{D}$ forages was significantly lower than that for $\mathrm{H}$ stage $(62.9,56.3$ and 56.6 , respectively for $\mathrm{H}$, $\mathrm{M}$ and $\mathrm{M}-\mathrm{D} ; \mathrm{P}<0.001)$.

It can be concluded that in terms of protein availability, the milk stage of growth seems to be the optimal harvest time.

TABLE 3

Total protein digestibility (TTPD) and intestinal digestibility of rumen-undegraded protein (IDRUP) of whole-crop oat before and after ensiling

\begin{tabular}{lcc}
\hline Item & TTPD, \% & IDRUP, $\%$ \\
\hline $\begin{array}{l}\text { Before ensiling } \\
\text { heading }\end{array}$ & 88.9 & 69.8 \\
milk & 90.3 & 60.6 \\
milk-dough & 85.9 & 60.9 \\
Silage & &. \\
heading & 90.5 & 56.5 \\
milk & 88.1 & 53.4 \\
milk-dough & 88.7 & 53.1 \\
SEM & 0.2 & 0.7 \\
Effect & & \\
feed & $* * *$ & $* * *$ \\
cut & $* *$ & NS \\
interaction & $* * *$ & \\
** $-\mathrm{P}<0.01 ; \quad * * *-\mathrm{P}<0.001 ;$ & NS - not significant &
\end{tabular}

\section{REFERENCES}

Borowiec F., Furgał K., Kamiński J., Zając T., 1998. Nutritive value of made of whole crop barley harvested at various stages of maturity. J. Anim. Feed Sci. 7, 45-54

Coblentz W.K., Coffey K.P., Turner J.E., Scarbrough D.A., Weyers J.S., Harrison K.F., Johnson Z.B., Daniels L.B., Rosenkrans C.F. Jr., Kellogg D.W., Hubbell III D.S., 2001. Ruminal nitrogen disappearance from sod-seeded cereal grain forages in Northern Arkansas. Anim. Feed Sci. Tech. 89, 17-32

Czauderna M., Kowalczyk J., 1999. Determination of 2,6-diaminopimelic acid in bacteria, ruminal and duodenal digesta using HPLC with fluorescence or UV detection. J. Anim. Feed Sci. 8, 273-288 
Edmisten K.L., Green J.T. Jr., Mueller J.P., Burns J.C., 1998. Winter annual small grain forage potential. II. Quantification of nutritive characteristics of four small grain species at six growth stages. Commun. Soil Sci. Plant Anal. 29,881-899

Garnsworthy P.C., Stokes D.T., 1993. The nutritive value of wheat and oat silage ensiled on three cutting dates. J. Agr. Sci. 121, 233-240

Khorasani G.R., Jedel P.E., Heln J.H., Kcnuelly J.J., 1997. Influence of stage of maturity on yield components and chemical composition of cereal grain silages. Can. J. Anim. Sci. 77, 259-267

Kowalski Z. M., Pisulewski P. M. P., Peyraud J-L., Kamiński J., 1995. The effect of drier outflow temperature on rumen protein degradability and intestinal digestibility of rumen-undegraded protein of dehydrated grass and lucerne. Ann. Zootech. 44, Suppl., 88 (Abstr.)

Kowalski Z. M., Marszałek A., Mills C.R., 1997. The use of Ca salts of rape seed fatty acids to protect protein against degradation in the rumen. Anim. Feed Sci. Tech. 65, 265-274

Micek P., Borowiec F., Kowalski Z.M., 2001. Starch digestion of whole grain crop silages in ruminants. J. Anim. Feed Sci. 10 (in press)

Orskov E.R., Mc Donald, 1979. The estimation of protein degradability in the rumen from incubation measurements weighted according to rates of passage. J. Agr. Sci. 92, 499-503

SAS, 1995. Release 6.11. SAS Institute Inc., SAS Campus Drive, Cary, NC

\section{STRESZCZENIE}

Wplyw zakiszania oraz fazy wzrostu calych roślin owsa na rozklad bialka w żwaczu i strawność jelitową białka nic ulegającego rozkładowi w żwaczu

Badano rozkład białka w żwaczu oraz strawność jelitową białka nic rozłożoncgo $w$ żwaczu (IDRUP) $z$ całych roślin owsa zebranych $w$ fazic kloszenia oraz dojrzałości mlecznej lub mlecznowoskowej ziarna. Doświadczenie wykonano na trzech buhajkach z przetokami do żwacza i dwunastnicy, stosując metody in situ (rozkład w żwaczu) i woreczków jelitowych (strawność jelitowa).

Wykazano istotny wpływ procesu kiszenia na wskaźniki rozkladu białka w żwaczu. Zakiszanie zwiększało udzial frakcji A oraz efektywny rozkład białka w żwaczu (ERD), a zmniejszało udział frakcji $\mathrm{B}$, tj. potencjalnie ulegającej rozkładowi $(\mathrm{P}<0,00 \mathrm{l})$. Zakiszanie zmniejszało także IDRUP $(64,7$ vs $55,3 \% ; \mathrm{P}<0,001)$.

Przedłużanie okresu wzrostu roślin do dojrzałości mlecznej ziarna zwiększało udział frakcji rozpuszczainej A oraz ERD i zmniejszało udział frakcji B. Dalsze przedłużanic wzrostu do fazy dojrzałości mleczno-woskowej zmniejszało istotnie udział frakcji A $(75,6$ vs 70,5$)$ i ERD $(80,6$ vs 78,2$)$. Wraz z dojrzewaniem roślin zmniejszała się strawność białka w całym przewodzic pokarmowym $(\mathrm{P}<0,001)$. Ponadto, IDRUP pasz zebranych w fazie mlecznej i mleczno-woskowej dojrzalości ziar* na było istotnie mniejsze niż zebranych w fazie kłoszenia $(62,9 ; 56,3$ i 56,6 , odpowiednio dla fazy kłoszenia, mlecznej i mleczno-woskowej; $\mathrm{P}<0,00$ l).

Wydaje się, że optymalnym okresem zbioru całych roślin owsa z przeznaczeniem do zakiszania jest dojrzałość mleczna ziarna. 